\title{
坩堝回転機構付垂直ブリッジマン法で育成した $\mathrm{Bi}_{2} \mathrm{Sr}_{2} \mathrm{CaCu}_{2} \mathrm{O}_{\mathrm{y}}$ 超伝導単結晶の光電子分光*
}

\author{
田中 博美*1 · 永島法*1 · 岸田 悟*1 ·吉川 英樹*2 \\ 木村 昌弘*2 ・田中 彰博*3 · 福島 整*2 \\ （受理2002年11月 22 日, 掲載決定2003年 3 月 1 日）
}

\author{
XPS Study on the $\mathrm{Bi}_{2} \mathrm{Sr}_{2} \mathrm{CaCu}_{2} \mathrm{O}_{\mathrm{y}}$ Single Crystals Grown \\ by a Vertical Bridgman Method with Crucible-Rotation System* \\ Hiromi TANAKA*1, Osamu NAGASHIMA*1, Satoru KISHIDA*1, \\ Hideki YOSHIKAWA*2, Masahiro KIMURA*2, \\ Akihiro TANAKA*3 and Sei FUKUSHIMA*2 \\ ${ }^{* 1}$ Tottori University, 4-101, Koyama-Minami, Tottori 680-8552, Japan \\ ${ }^{* 2}$ Harima Office, Advanced Materials Laboratory, National Institute for Materials Science, \\ Kohto 1-1, Mikazuki, Sayo, Hyogo 679-5143, Japan \\ ${ }^{* 3}$ ULVAC-PHI, Inc. 370 Enzo, Chigasaki, Kanagawa 253-0084, Japan
}

(Received November 22, 2002, Accepted March 1, 2003)

We carried out surface cleaning of $\mathrm{Bi}_{2} \mathrm{Sr}_{2} \mathrm{CaCu}_{2} \mathrm{O}_{\mathrm{y}}$ ( $\left.\mathrm{Bi}-2212\right)$ single crystals grown by a modified vertical Bridgman method (modified VB method), and investigated the chemical state with X-ray photoelectron spectroscopy.

From the results, we found that carbon impurities on the surface of the single crystals can be removed almost completely by cleaving them under high vacuum $\left(7.3 \times 10^{-6} \mathrm{~Pa}\right)$. The $\mathrm{O}-1$ s peak from the cleaved surface of the single crystal was very sharp and its FWHM value was about $2.0 \mathrm{eV}$. Moreover, we found that the crystals do not include any carbon impurities, and that they have few mutual substitutions between $\mathrm{Ca}$ and $\mathrm{Sr}$. Therefore, the single crystals grown by a modified VB method is found to have high quality.

\section{1. 序論}

銅酸化物高温超伝導体（以下，高温超伝導体）の発見 以来 ${ }^{1-5)}$, その発現機構を解明すべく数多くの研究が行 なわれてきた．高温超伝導体の発現機構を解明する為に は, 高温超伝導体の化学状態を厳密に明らかにする必要 がある、しかしながら，その研究には極めて清浄な単結

* 平成14年10月17日 第43回真空に関する連合講演会で発表

*1 鳥取大学（宁680-8552 鳥取市湖山町南 4丁目 101)

*2 独立行政法人物質 - 材料研究機構物質研究所はりまオフィス (宁679-5143 兵庫県佐用郡三日月町光都 1-1-1 Spring-8 BL15XU)

*3 アルバック・ファイ侏（テ253-0084 神奈川県茅ヶ崎市円蔵370）
晶表面が必要である. 高温超伝導体の中でも特に Bi 系 超伝導単結晶は, その結晶構造から䢃開性に優れており 容易に配向性のある平坦な面が得られる。その為, Bi 系超伝導単結晶は清浄表面を必要とする物性測定には大 変適している. 特に $\mathrm{Bi}_{2} \mathrm{Sr}_{2} \mathrm{CaCu}_{2} \mathrm{O}_{\mathrm{y}}(\mathrm{Bi}-2212)$ 単結晶 は, 近年の単結晶育成技術の目覚しい進歩により, 比較 的容易に良質な単結晶が得られるようになってきてい $る^{6-11)}$. そして, 最近, 改良垂直ブリッジマン法（改良 VB 法）を用いる事により，大型で高い結晶性を持ち， 且つ, 不純物や久陷の少ない高品質な Bi-2212単結晶が 得られたとの報告がある12,13). しかしながら, その単結 晶の化学的状態は厳密に明らかにされていない。 


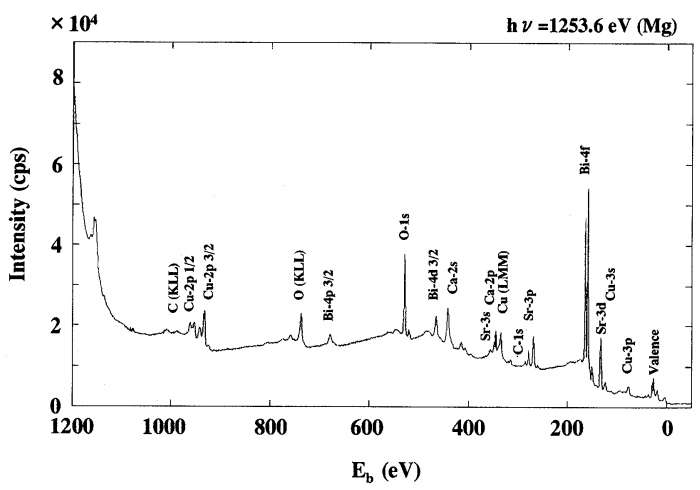

Fig. 1 XPS full spectra of as-grown single crystal.

本研究では, 改良 VB 法により育成した単結晶の化学 的状態を明らかにする為に，まず表面清浄化を試み，そ して得られた清浄面を X 線光電子分光（XPS）により 測定した.

\section{2. 実験方法}

本研究では, 改良 VB 法で育成された Bi-2212単結晶 を用いた。単結晶の育成条件は温度勾配: $3.3^{\circ} \mathrm{C} / \mathrm{mm}$, 育成開始温度 : $1000^{\circ} \mathrm{C}$, 坩堝回転速度 : $25 \mathrm{rpm}$ であ る. その単結晶の臨界温度 $\left(\mathrm{T}_{\mathrm{c}}\right),(0010) \mathrm{X}$ 線回折ピー クの半值幅はそれぞれ $82 \mathrm{~K}, 0.05^{\circ}$ であった。

清浄な単結晶表面を得る為, 種々の雾囲気下での䢃開 を行った．雰囲気としては大気， $\mathrm{N}_{2}$ ガス，高真空（7.3 $\left.\times 10^{-6} \mathrm{~Pa}\right)$ を採用した。 XPS 分析装置としては，Spring-8 BL15XU（物質・材料研 物質研）内に設置され ている DAPHNIA (ULVAC-PHI 製) を用いた。装置 の分解能を示す $\mathrm{Ag}-3 \mathrm{~d}_{5 / 2}$ ピークの半值幅は Pass Energy $23.5 \mathrm{eV}$ に扣いて約 $1.0 \mathrm{eV}$ であった. 又, 真空度と $\mathrm{X}$ 線 源はそれぞれ $3 \times 10^{-7} \mathrm{~Pa}$ 以下, $\mathrm{MgK}_{\alpha}(1253.6 \mathrm{eV})$ で あった。

又, 単結晶が炭素を結晶内部に含んでいるかどらかを 判断する為に, 表面に $\mathrm{Ar}^{+}$エッチングを施し炭素ピー クの強度変化の様子を観測した。

\section{3. 結果と検討}

Fig. 1 に改良 VB 法で育成した単結晶のXPSフルス ペクトルを示す. 図に示すよらに得られたスペクトルは C-1s を除いて, すべて Bi-2212の構成元素のみで同定 された。

Fig. 2 に種々の雲囲気下で䢃開した Bi-2212単結晶表 面より観測された O-1s ピークを示す。この図から分か るように, 高真空 $\left(7.3 \times 10^{-6} \mathrm{~Pa}\right)$ 中で辟開した単結晶

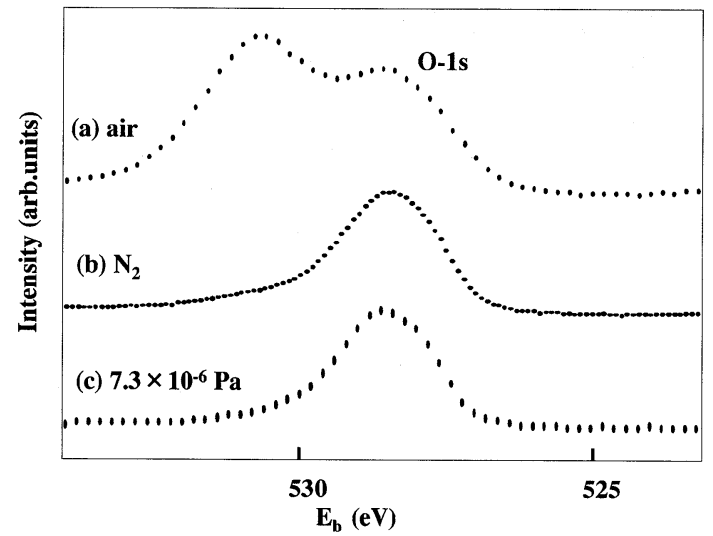

Fig. 2 O-1s spectra of as-grown single crystals cleaved in (a) air, (b) $\mathrm{N}_{2}$ gas and (c) $7.3 \times 10^{-6} \mathrm{~Pa}$.

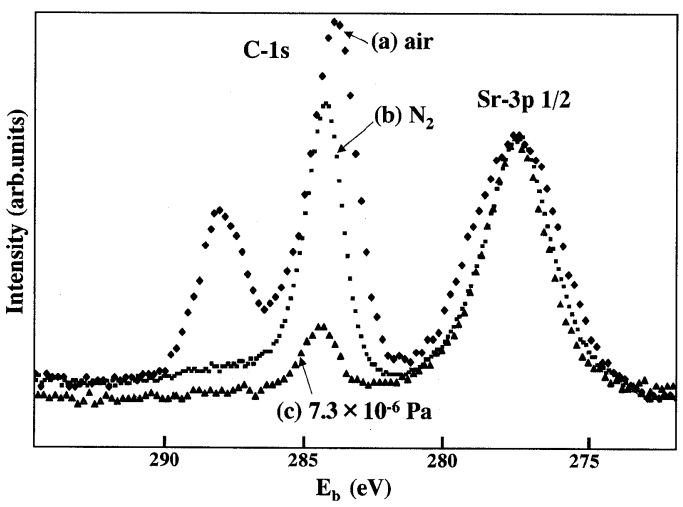

Fig. 3 C-1s spectra of as-grown single crystals cleaved in (a) air, (b) $\mathrm{N}_{2}$ gas and (c) $7.3 \times 10^{-6} \mathrm{~Pa}$.

表面から得られた O-1s ピーク（529 eV 付近）は非常に 鋭く, $531 \mathrm{eV}$ 付近の高束縛エネルギー側 $\left(\mathrm{E}_{\mathrm{b}}\right)$ に生じ る不純物酸素によるピークが観測されない事が分かる. 高真空中䢃開面より得られた鋭い $\mathrm{O}-1 \mathrm{~s}$ ピークの半値幅 は約 $2.0 \mathrm{eV}$ であった。一方， $\mathrm{N}_{2}$ ガス中で䢃開した単結 晶表面から得られる $\mathrm{O}-1 \mathrm{~s}$ ピークは若干ブロードであ る.これは，表面に付着した不純物酸素による化学状態 が混在していると考えられる，又，大気中䢃開した単結 晶表面からは $\mathrm{OH}^{-}$の付着によるものと考えられるピー クも観測された.

Fig. 3 はそれぞれ種々の雲囲気下で䢃開した単結晶の 表面より得られた $\mathrm{C}-1 \mathrm{~s}$ ピークを示す。この図から，大 気中䢃開時には不純物炭素のピークが極めて大きい事が 分かる. 一方で高真空中䢃開を行らと，不純物炭素ピー クが大幅に減少する事が分かる，しかしながら，単結晶 


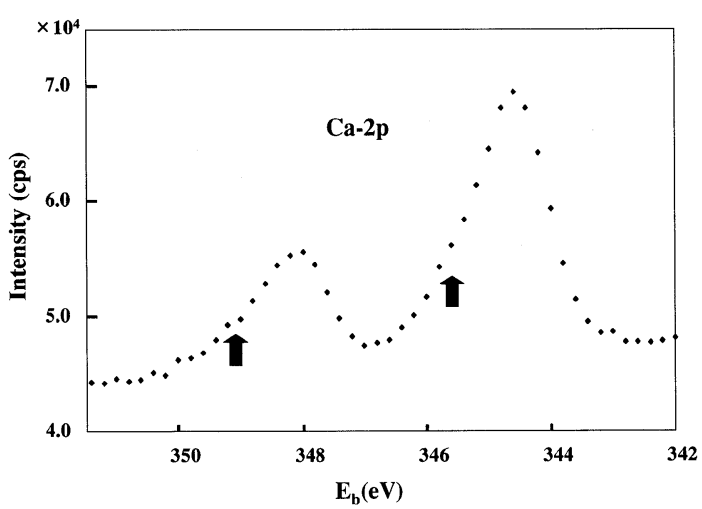

Fig. $4 \mathrm{Ca}-2 \mathrm{p}$ spectrum of as-grown single crystal cleaved in $7.3 \times 10^{-6} \mathrm{~Pa}$.

育成に拈いて原材料に炭酸化物を用いている為, この観 測された炭素は表面に付着したものではなく, 結晶内部 に存在する炭素である可能性が否めない。そこで, $\mathrm{Ar}^{+}$ エッチングを行い炭素の存在位置を明らかにした，その 結果, $\mathrm{C}-1 \mathrm{~s}$ ピークは $\mathrm{Ar}^{+}$エッチングにより，ほぼ消滅 した（Fig. 4)。これより，炭素は表面のみに存在し， 改良 VB法により育成した単結晶は原材料からの不純物 炭素による污染がない事が分かる．この不純物炭素は， より高い真空中で䢃開するか，又は加熱処理を施す事に より完全に除去できるものと思われる ${ }^{14)}$.

Fig. 4 亿高真空 $\left(7.3 \times 10^{-6} \mathrm{~Pa}\right)$ 中辟開した単結晶表

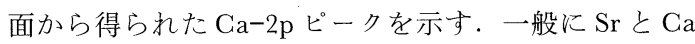
は非常に固溶置換しやすい元素である、Bi-2212単結晶 に扣いても，この置換が生じ超伝導特性に影響を与えて いると考兄れている．この固溶置換により $\mathrm{Ca}-2 \mathrm{p}$ 抒 よび $\mathrm{Sr}-3 \mathrm{~d}$ ピークには，それぞれ高 $\mathrm{E}_{\mathrm{b}}$ 側に別のピーク が生じ結果としてスペクトルは全体としてブロードにな る ${ }^{15-16)}$ 、しかしながら, 四から分かるように345と348 $\mathrm{eV}$ 付近の $\mathrm{Ca}-2 \mathrm{p}$ ピークは非常に鋭かった. 従って, 改 良 VB法で育成した単結晶では Caサイトを $\mathrm{Sr}$ が占有 する事により生じるピークが極めて小さい事が分かる.

この結果から, 改良 VB 法で育成した単結晶は $\mathrm{Sr}$ と $\mathrm{Ca}$ の固溶置換が抑えられている事が分かる.

以上の結果から, 改良 VB 法で育成した Bi-2212単結 晶は非常に良質で化学状態を厳密に議論するのに適した 単結晶であると言える。

\section{4. 結 論}

本研究では, 改良 VB 法により育成した Bi-2212単結 晶の化学的状態を明らかにする為に, 表面清浄化を試 又, 得られた清浄面をXPSにより測定した。

その結果, 高真空 $\left(7.3 \times 10^{-6} \mathrm{~Pa}\right)$ 中で䢃開を行ら事 で不純物炭素の大幅な減少に成功した。この時, O1s

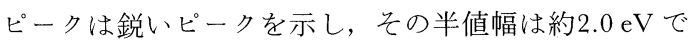
あった。 又, 観測された炭素は表面に付着したものであ り, 単結晶内部には不純物炭素がない事が分かった. 又, $\mathrm{Ca} 2 \mathrm{p}$ ピークでは $\mathrm{Ca}$ と $\mathrm{Sr}$ 置換により高 $\mathrm{E}_{\mathrm{b}}$ 側に生じる ピークの成分が非常に小さい事が分かった. 以上の結果 から, 改良 VB 法で育成した単結晶は不純物炭素を含ま ず，更には Ca と Sr の固溶置換が少ない良質な単結晶 であると考觉られる。

\section{〔文献〕}

1) J. G. Bednorz and K. A. Muller: Z. Phys., B 64 (1986) 189.

2) M. K. Wu, J. R. Ashburn, G. J. Torng, P. H. Hor, R. L. Meng, L. Gao, Z. J. Huang, Y. Q. Wang and C. W. Chu: Phys. Rev. Lett., 58 (1987) 908.

3) H. Maeda, Y. Tanaka, M. Fukutomi and T. Asano: Jpn. J. Appl. Phys., 27 (1988) L209.

4) Z. Z. Sheng and A. M. Hermann: Nature, 332 (1988) 138.

5) A. Schilling, M. Cantoni, J. D. Guo and H. R. Ott: Nature, 363 (1993) 56.

6) S. Takekawa, H. Nozaki, A. Umezono, K. Kosuda and M. Kobayashi: J. Grystal Growth, 92 (1998) 687.

7) A. Ono, S. Sueno and F. P. Okamura: Jpn. J. Appl. Phys., 27 (1998) L786.

8) A. Tanaka, S. Kishida, A. Shibasaki, H. Tokutaka and K. Fujimura: Jpn. J. Appl. Phys., 36 (1997) L761.

9) A. Tanaka, S. Kishida, A. Shibasaki, E. Hosokawa and H. Tokutaka: J. Crystal Growth, 182 (1997) 60.

10) S. Kishida and E. Hosokawa: J. Crystal Growth, 192 (1998) 136.

11) S. Kishida, M. Nakamura and W. Y. Liang: J. Crystal Growth, 216 (2000) 220.

12) H. Tanaka, M. Nakamura and S. Kishida: Physica, C 357-360 (2001) 722 .

13) H. Tanaka and S. Kishida: J. Crystal Growth, 237239 (2002) 749.

14) S. Kishida, H. Tokutaka, S. Nakanishi, K. Nishimori, N. Ishihara and H. Fijimoto: Jpn. J. Appl. Phys., 28 (1989) L406.

15) S. Kohiki, T. Wada, S. Kawashima, H. Takagi, S. Uchida and S. Tanaka: Phys. Rev., B 38 (1988) 7051.

16) S. Kohiki, T. Wada, S. Kawashima, H. Takagi, S. Uchida and S. Tanaka: Phys. Rev., B 38 (1988) 8868. 